\title{
Internalization of Character Values in Pesantren School: Efforts of Quality Enhancement
}

\author{
A. Faizin \\ Department of Educational Management \\ Universitas Negeri Surabaya \\ Surabaya, Indonesia. \\ afaizin.18008@mhs.unesa.ac.id
}

\begin{abstract}
Educational institutions have sought a solution to improve quality, one of them is by making efforts to cultivate moral-based values in order to improve the effectiveness of education. The purpose of this study was to determine the internalization of character values in Pesantren school, and the implementation of character values in an effort of quality enhancement. Descriptive qualitative research methods will describe the internalization of character values and quality of education. Data collected through observations are processed through recording, typing, or rearranging. Formal schools in Islamic boarding schools have carried out character education through their curriculum and activities. In it there are efforts that are designed and implemented systematically to help students understand the values of human behavior. Moral knowing, moral feeling, moral action, habit and value are compositions of character values that are internalized to develop the quality of education.
\end{abstract}

Keywords-character value; pesantren school; quality of education

\section{INTRODUCTION}

In the development of education in the era of globalization, formal education in Islamic boarding schools is seen as an alternative to building the moral (character) of the nation's children. Early character values must be instilled in the nation's children in school. Characters have deep meanings, not just attitudes that are reflected by behavior, but also related to the motives underlying an act. This is certainly an important part in developing education, so schools in the pesantren (Islamic boarding school) in the process are expected to be a quality and quality character school. Islamic boarding schools in practice apply the traditional education system by maintaining tradition and remaining based on Islamic values and teachings. Islamic boarding schools are the oldest and typical education in Indonesia that have contributed greatly to the development of the nation and state of Indonesia [1]. Islamic boarding schools as organizers of education have given birth to schools or Madrasah.

Islamic boarding schools are a manifestation of the renewal of the education system. in modern pesantren there is a classical learning system, which includes general education in the Madrasah school curriculum. In improving the quality of education [2], Pesantren school always uphold the truth, honesty and uphold democratic principles, human rights, environmental preservation. Schools in Islamic boarding schools are expected to play a role not only in taking an active position in shaping the character of the nation, but also able to create the dynamics of the national movement, eradicate the culture of corruption, poverty and create economic growth in society.

In its role, pesantren school is very active in instilling character values. The intensity of the influence of Islamic boarding schools as organizers of education has made boarding-based schools play an important role in the process of forming children's personality.

With its management, the pesantren school contains a grouping of lessons on Islamic knowledge and general knowledge. With this grouping learning is not only at the cognitive level, but also touches on internalization and real experiences that exist in society. This is in line with the direction of character education in Indonesia, namely school management is one of the effective media in character education in Indonesia [3].

Islamic boarding schools as an institution of character building face various challenges of modern life that tend to be materialist, opportunist, and hedonic. This is certainly very relevant to the present condition of society [1]. Internalization of character values in schools within boarding schools is not only built through learning and strengthening attitudes but also through intensively invested values everyday. In particular, the pesantren school environment is very supportive for controlling the behavior of students. Through the development of these values, it is hoped that it will not only affect the quality of students at school, but also on the quality of educational institutions. Basically, educational institutions or pesantren schools have sought a solution to improve quality, one of which is to plant character-based values that include moral / religious values. This is to be able to increase the effectiveness of all components. Madrasah Aliyah (MA) Al Ishlah is one of the schools in an Islamic boarding school, established in 2014. The school has absorbed students who live outside and inside boarding schools. The development of character values has become a culture that is built on institutions that have character. The character that continues to be instilled and implemented is expected to provide a positive climate for the development of school quality. On the other hand, the government as the person in charge of education has spent a lot of money where the funds that finance an education quality improvement project, but still cannot achieve maximum results in various programs that have been implemented in order to improve the quality of education.

This exposure focuses on 1). Internalization of character values at the MA Al Ishlah Bungah Gresik Islamic boarding school 2). Implementation of character values in an effort of 
quality enhancement of education at the MA Al Ishlah Bungah Gresik Islamic boarding school.

Previous research was used to examine studies related to character values and educational quality. Research on educational quality has been carried out by the strategy of internalizing Islamic character values in Entrepreneur-based Al Mumtaz Islamic Boarding School Islamic Boarding School and Tahfidz by Muhammad Iplih, 2016. Among the research results are strategies used in internalizing Islamic character values in Al Mumtaz Islamic boarding school is a) exemplary strategy, that is through exemplary some characters can be formed in a santri is responsible, independent, humble and honest, b) custom, c) moral knowing d) weekly moral value program.

Research on the tradition of boarding schools by Munadi, 2018, with the results of research that Islamic education is a manifestation of the ideals of life to preserve, instill and transform Islamic values to the next generation in the advancement of time and technology. Islamic boarding schools have a real contribution to education development. However, it is necessary to describe what types of Islamic boarding schools will be correlated with the educational institutions in them. This is very important because the patterns and models between salaf (traditional), semitraditional and modern pesantren have different educational models that will have an impact on formal education, of course there are also different processes of internalizing the character values of students. This study aims to determine the characteristics of traditional Islamic boarding school based character education, in this study the MA Al Ishlah school is a formal educational institution under the auspices of the Al Ishlah Islamic Boarding School which is a semimodern boarding school. Efforts to develop the practice of character building are very important to overcome the moral and character crisis, which has occurred at the individual and collective level reflected in educational institutions from elementary school to higher education. From previous research [4] there was a review of the implementation of pesantren tradition-based character education in it. This has become a differentiator of the author's study, namely the focus on the internalization of character values in boarding schools.

\section{A. Internalization of Characters}

Generational improvement commitment through national education serves to develop and shape dignified national character and civilization in order to educate the nation's life, aiming at developing the potential of students to become human beings who believe and fear God Almighty, have noble character, are healthy, knowledgeable, capable, creative, be independent, and become a democratic and responsible citizen.

Character is not inherited, One builds one day by the way thinks and acts, thought by thought, action by action (Helen G. Douglas). Character formation is also inseparable from the role of the teacher, because everything that is done by the teacher is able to influence the character of the students. Character is formed from three kinds of interrelated parts namely moral knowledge, moral feeling, and moral behavior. Character is a steady, stable, special trait inherent in the person who makes him behave and act spontaneously, cannot be influenced by circumstances and without needing prior thought [5].

According to the Ministry of Education and Culture there are 18 character values that must be developed in every level and education unit in Indonesia. These values are: (1) Religious; (2) Honest; (3) Tolerance; (4) Discipline; (5) Hard work; (6) Creative; (7) Mandiri; (8) Democratic; (9) Curiosity; (10) The spirit of nationalism or nationalism; (11) Love the homeland; (12) Appreciating achievements; (13) Communicative; (14) Love of peace; (15) Love reading; (16) Environmental care; (17) Care for social; and (18) responsibility.

The world of education is expected to be a vehicle that facilitates character development, so that all elements of the community funding school will have good awareness, ethics and behavior. An ethic in school education currently focused on students, ignoring students as the subject of dialogue, in the view of pedagogical work attitude is dogmatic attitude and discrimination in the school environment [6].

The results of education are indeed impossible to see and feel in a short time, but can be seen for a long time, maybe even after a generation. That is why the education process should not be wrong or wrong even if only a little. Mistakes made by people who are not experts in the field of education can damage one generation afterward and the consequences will continue. That is why planting character must continue to grow in educational institutions, especially educational institutions in boarding schools.

Four characters: religiosity, obedience, independence and soul like helping, make the indegenousitas stronger to be an identity of synergy that is able to connect the emotion of Indonesianness and independence so that the boarding school functionally has the appropriateness to be referred to as a national system that enables education orientation to be more easily achieved [7].

Schools in Islamic boarding schools have prepared educational programs to educate their students to have personality and competencies oriented to the world and the hereafter, and are expected to have the knowledge and skills needed for the progress of the school. Some descriptions of the effects of personality on behavioral problems and benefits can increase stress resistance and maintain a lifetime of psychological well-being by developing a mature personality. The process of internalizing characters in pesantren schools is about what is taught both in formal education and the environment of boarding schools can be embedded and function as a conscience and internalized and practiced in life by students [8]. Because character internalization is very important in order to improve the quality of learning of students and the quality of the school as a whole.

\section{B. School Quality}

Definition of quality means the degree (level) of the superiority of a product (work / effort) in the form of goods 
or services; both tangible and intangible. In the context of education the definition of quality, in this case refers to the process of education and educational outcomes. A school that is oriented to "quality" is required to always move fully dynamically to innovation efforts, and to condition itself as a learning institution or organization that always pays attention to the demands of the growing needs of society. According to Fattah, the quality of education is an ability (ability) that is owned by a product or service (service) that can meet the needs or expectations, satisfaction (satisfaction) at the customer (customers). In education, a very important and growing thing is how to improve the quality of education over time and time [9].

Education in Indonesia is a bit difficult to keep up with the development of quality, especially those whose education is still relatively low. How can you follow a development if something that becomes a problem cannot be overcome first, for example the lack of management and planting of character values in the school. Various efforts made by the government in Indonesia to solve the problem. The implementation of an increase in the quality of education in Indonesia which has been widely carried out but still cannot or has not been directly given an effect that is an improvement in the quality. As some efforts have been made by the government to improve the quality of education in Indonesia, one of them is an effort to change and improve the curriculum or several projects that are greatly increased such as internalizing character values. In education there are several elements, where the first element is the teaching curriculum that should be taught to students and should be given a priority that should be accepted in Indonesia. In certain subjects can result in character strengthening. Utilizing literary works can be considered an effective method for character education in schools. Analyzing the nature of positive characters through literary works evokes the ethical imagination students have. Second is an energy where the education of a teacher is only giving something that exemplifies a good one, not a few teachers become teachers of education. Third in education is where students are given a motivation because they have to learn and also motivate is needed to increase an interest in student learning.

Education is a major factor in the formation of the human personality. Education is very instrumental in shaping the good or bad of human persons according to normative measures. Realizing this, the government is very serious in handling the education sector, because with a good education system it is hoped that the next generation will emerge that is qualified and able to adapt to live in a society, nation and state. The decline in the quality of education in Indonesia in general and the quality of higher education in a sfesific manner seen from a macro perspective can be caused by the poor national education system and low human resources [11].

Based on this fact, the school under the auspices of the pesantren as a humanitarian institution encourages the creation of a prosperous society, so that a number of community expectations for pesantren are pesantren should be agents of reformation as well as equal partners of the government, and take full part in solving actual problems in developing quality education in Indonesia. The quality of education in Islamic boarding schools is a standard quality about the process of changing behavior within a group through teaching and training guidance, which is in the field of education which includes the quality of input, process, output, and outcome.

\section{METHOD}

The design of this study uses a case study, where researchers develop an in-depth analysis of a case [12]. This focuses on the concepts or phenomena that exist in an institution, especially in the internalization of character values in pesantren schools and efforts to improve quality. The case is limited by time and activity.

The informants from this study were students at $\mathrm{Al}$ Ishlah boarding school. The main informants are students at Madrasah Aliyah al Ishlah. In conducting observations this research looks at the components that are in the school, namely the Principal, the teacher and the boarding school environment.

The method of data collection is obtained through various methods such as observation, recording essence (open questions), documents and audio visual which are then processed through recording, typing, or rearranging the data [13].

According to Huberman in qualitative analysis of data that appears in the form of words and not a series of numbers. Based on the data analysis theory [14], the analysis of this research data follows Huberman's analysis which includes the process of selecting, focusing, simplifying, abstracting and transforming rough data that appears from written records in the field. This data reduction starts from the beginning of data collection until the report administrator. In the presentation obtained a set of structured information that gives the possibility of drawing conclusions and taking action.

\section{RESULTS AND DISCUSSION}

Formation of good character is one of the keys to education in schools based on character education. Many religious-based formal schools in Indonesia carry out this character internalization even though the school provides students with character education through their curriculum and activities. Islamic boarding schools have a strategic position to help oversee the development of character education. Character education is efforts that are designed and implemented systematically to help students understand the values of human behavior in the practice of life in society. In the process of education, the internalization of cultural values and character at MA Al Ishlah is one of the efforts to prevent the occurrence of ethical and moral degradation among adolescents, the internalization of characters is taught both in formal education and the pesantren environment, this is embedded and serves as a conscience and lived and practiced with interactions between teachers and students. Internalization of character 
through interactions built with the academic atmosphere in the school can determine student achievement [15].

Education in islamic boarding schools has enriched students' minds with textual and contextual explanations through communication with teachers. A process of communication between student teachers is very important to create positive and negative emotions. The teacher's knowledge of the factors that determine their formation can largely contribute to better control of them and, consequently, create smooth communication, significantly improve learning both sides of the educational process [15]. In it there is also the appreciation of spiritual and humanitarian values, honest attitudes and behavior as well as simple life and independence.

This is reflected in the character concept, namely moral knowing which includes moral awareness, knowledge of moral values, foresight, moral reasoning, decision making and self-knowledge, which are essential things that need to be taught to students. However, character education as limited as moral knowing is not enough. For that, it needs to continue to the moral feeling which includes conscience, self-confidence, empathy, kindness, self-control and humility. It even continues at the most important stage, namely moral action. It is important because at this stage the motive for encouraging someone to do good is seen in the aspects of competence, desires and habits that are displayed. Habit as a support for activities that exist in boarding schools, through habituation that is driven by the rules and culture that exist in boarding schools. Value is the composition of character values that are internalized in every level and education unit to develop the quality of education in Indonesia.

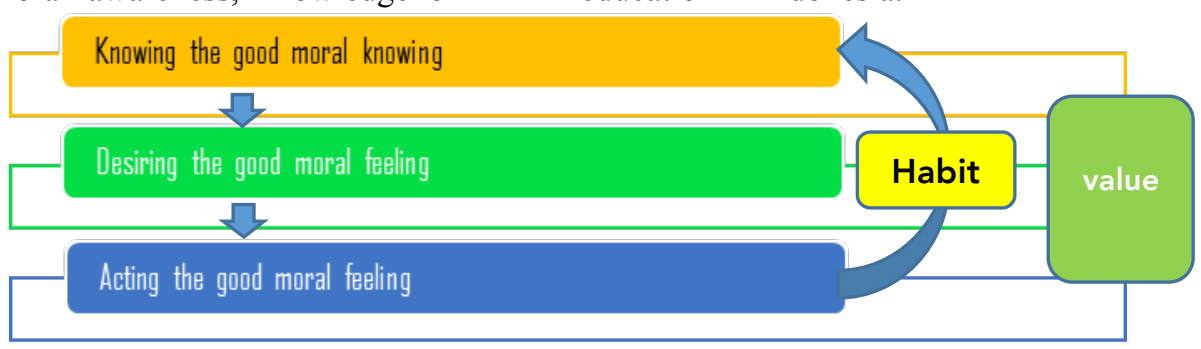

Fig. 1. Character value cycle in Islamic boarding schools

Many religious-based formal schools in Indonesia carry out character education like this even though the school provides students with character education through their curriculum and activities.

Islamic boarding schools have a strategic position to help oversee the development of character education. Internalizing cultural values and character at MA Al Ishlah is one of the efforts to prevent the occurrence of ethical and moral degradation among adolescents, the internalization of characters is taught both in formal education and the environment of boarding schools, this is embedded and serves as a conscience and is internalized and practiced in life by students, namely the concept of character that is moral knowing, moral feeling, moral action, habit and value with a cycle that can foster character values that have implications for the quality of educational institutions.

Implementation of character education through: custom of worship before school, in class, rest, and before going home; provide advice inside and outside the learning process; teacher education in the application of character education; internalization by focusing on the dimensions and values of cognition, as well as extracurricular and religious programs, this is in accordance with the strategy of internalizing Islamic character values in Islamic Boarding Schools, the results of the study by Muhammad Iplih, 2016. There are similarities in the methods of exemplary and custom strategies

Islamic boarding schools have a real contribution to education development. Character values that are applied are: sincerity, honesty, responsibility, hard work, and tasammuh. research on the tradition of boarding schools by
Munadi, 2018, where Islamic education is an effort to preserve, instill, and transform Islamic values to the next generation in the advancement of time and technology. The research implications for education should be to provide knowledge as a solution to the complex problems that exist in schools through the application of boarding-based character education.

1. The description of this study is expected to be useful for schools, especially to find out the internalization of the value of character values in Islamic boarding schools in an effort to improve the quality of education in Indonesia.

2. This research can be utilized in the development of education through the character of government institutions in the field of education and culture.

3. This research is an academic reference, especially in terms of internalizing the value of character values in Islamic boarding schools in an effort to improve the quality of education in Indonesia.

4. This research can be used as a reference and material for the development of further research, especially on character education based on the pesantren tradition.

\section{CONCLUSION}

The results of the study illustrate the internalization of character values in boarding schools and the implementation of character values in an effort to improve the quality of education at the MA Al Ishlah Bungah Gresik Islamic boarding school. Formation of good character is one of the keys to education in schools based on character education. Many religious-based formal schools in Indonesia carry out character education like this even though schools provide 
students with character education through interaction, curriculum structure and pesantren-based activities.

In the education process, cultural and character values are one of the efforts to prevent the occurrence of ethical and moral degradation among students. With the concept of moral knowing, moral feeling and moral action the character that is carried out in continuity in the habit (Pesantren School) has become a supporting activity that produces values (character value values) that are implemented in every level and unit of education. The implementation of character values, at the MA Al Ishlah boarding school is carried out through 3 models, namely the structure of the curriculum, planting culture (habit) in the pesantren environment as well as the characteristics of the leader, this will have a positive effect on improving the quality of education in the School.

\section{REFERENCES}

[1] Sholicin, M.M, Rekonstruksi pendidikan pesantren sebagai character building menghadapi tantangan kehidupan modern; The Journal of Social and Islamic Culture. 2442-3289, 2012.

[2] Sutikno. M. Sobry, Manajemen Pendiidkan: Langkah Praktis Mewujudkan Lembaga Pendidikan yang Unggul. Lombok: Holistica, 2012.

[3] Samani. M \& Haryanto, Konsep dan Model Pendidikan Karakter. Bandung: Remaja Rosdakarya, 2012.

[4] Suherman Ayi, "The Implementation of Character Education Values in Integrated Physical Education Subject in Elementary School". SHS Web of Conferences;42:00045, 2018.

[5] Lickona, Thomas, Character Matters; Persoalan Karakter, Bagaimana Membantu Anak Mengembangkan Penilaian yang Baik, Integritas dan Kebajikan Penting Lainnya, Jakarta: PT. Bumi Aksara, 2015.

[6] Renato José Oliveira, Reflections on Ethics in School Education. Educação (UFSM) 2014;39 (1):105-116, 2014.

[7] Maimun, Muhammad, "Pesantren sebagai prototipe pendidikan nusantara”, Journal Islamuna: Jurnal Studi Islam: 2407 411, 2018.

[8] Lee SJ, Park SH, Cloninger CR, Chae H, "Behavior problems and personality in Korean high school students". PeerJ6:e6106, 2018.

[9] Fattah, Nanang, Sistem Penjaminan Mutu Pendidikan, Bandung: Remaja Rosda Karya, 2012.

[10] Halit Karatay, "Using Literary Works In Character Education," Turkish Studies. 1308-2140, 2011.

[11] Abdul Hadis dan Nurhayati, Psikologi Pendidikan. Jakarta: Rineka Cipta, 2010.

[12] Yin, R.K, Application of case study research (edisi ke 3). Thousand Oaks, CA:Sage, 2012.

[13] Creswell, J.W, Research Design, Qualitative, Quantitative, and Mixed Methods Approaches, Fourth Edition, SAGE Publication, Inc, 2014.

[14] Huberman A.M \& Miles, M.B, Analisis Data Kualitatif. Terjemahan oleh. Tjetjep Rohendi Rohidi. 1992. Jakarta : Penerbit Universitas Indonesia, 1984

[15] K. Wołodkiewicz, "The Teacher and Students in Terms of The Interaction Approach," Journal of Agribusiness and Rural Development. 4 (34) 225-231, 2014. 